\title{
Cytogenetic analysis in western Atlantic snappers (Perciformes, Lutjanidae)
}

\author{
Érika Cruz Rocha and Wagner Franco Molina \\ Departamento de Biologia Celular e Genética, Centro de Biociências, \\ Universidade Federal do Rio Grande do Norte, Natal, RN, Brazil.
}

\begin{abstract}
The Lutjanidae or snappers are a family of perciform fishes, mainly marine but with some members living in estuaries and entering fresh water to feed. Some are important food fish. Cytogenetic data for Lutjanidae are scarce. In the present work, we cytogenetically characterized through conventional Giemsa staining techniques, Ag-NOR and C-banding the species Ocyurus chrysurus, Lutjanus analis, L. alexandrei, L. cyanopterus, L. jocu and L. synagris, all found along the Brazilian coast. Karyotype analysis of all six species showed a modal value of $2 n=48$ acrocentric chromosomes. Single NORs were found at pericentromeric position on the long arms of the $2^{\text {nd }}$ pair in 0 . chrysurus, $L$. alexandrei and $L$. cyanopterus, on the $5^{\text {th }}$ pair in $L$. analis and on the $23^{\text {rd }}$ pair in $L$. synagris. The species $L$. jocu presented multiple NORs located on the $2^{\text {nd }}$ pair at a pericentromeric region and on the $5^{\text {th }}$ pair at a telomeric region. Heterochromatic blocks were identified at the centromeric region of all chromosomes of the studied species. These results indicate that, despite of the chromosomal stability of this family, a relative structural diversification seems to have occurred in the chromosome evolution of the group. Such diversification was evidenced by divergent number and location of ribosomal sites among species. The NOR-bearing pairs represented an efficient cytotaxonomic marker for most of the analyzed species. The data suggest that the presence of interstitially located single NORs on a large acrocentric pair should represent a basal condition for lutjanids.
\end{abstract}

Key words: chromosome evolution, fish cytogenetics, Lutjanidae, Lutjanus, Ocyurus.

Received: April 9, 2008; Accepted: April 16, 2008.

\section{Introduction}

Species from the family Lutjanidae represent one of the major resources for marine fishery (Resende et al., 2003). This family comprises 17 genera and nearly 105 species mainly inhabiting the marine realm, with few species living in estuarine environments. Lutjanids are widespread over reef areas of tropical and subtropical regions, throughout Atlantic, Pacific and Indian oceans (Nelson, 2006). In Brazil, they are distributed along the entire seashore, where four genera from two subfamilies (Etelinae and Lutjaninae) are reported: Lutjanus, comprising eight species (Moura and Lindeman, 2007), and the monotypic genera Ocyurus, Rhomboplites and Etelis (Cervigón, 1993). Lutjanids are represented by medium to large demersal fish species up to $1 \mathrm{~m}$ in length or more that are able to live at great depths, and are popularly known as snappers (Nelson, 2006). They are great predators, playing a major role on their ecosystem (España, 2003). Most species from this family grow slowly, are long-lived (20 to 30 years) (Polovina and Ralston,

Send correspondence to Wagner Franco Molina. Departamento de Biologia Celular e Genética, Centro de Biociências, Universidade Federal do Rio Grande do Norte, Campus Universitário, 59078-970 Natal, RN, Brazil. E-mail molinawf@yahoo.com.br.
1987), and are highly vulnerable to overfishing (Coleman et al., 2000).

Up to now, cytogenetic data in Lutjanidae have been published only for some species; Lutjanus argentimaculatus $(2 \mathrm{n}=48 \mathrm{a})$ (Raghunat and Prasad, 1980), L. kasmira $(2 \mathrm{n}=48 \mathrm{a})$ (Choudhury et al., 1979), L. sanguineus $(2 \mathrm{n}=48 \mathrm{a})$ (Rishi, 1973), and $L$. quinquelineatus $(2 \mathrm{n}=48$, female; $2 \mathrm{n}=47$, male) (Ueno and Takai, 2008). Based on both ecological and economical relevance of the family Lutjanidae, coupled with the lack of genetic information about the group, the goal of the present study was to cytogenetically analyze the species Lutjanus analis, L. alexandrei, L. cyanopterus, L. jocu, L. synagris and Ocyurus chrysurus, from the northeastern coast of Brazil, through conventional Giemsa staining, Ag-NOR and C-banding.

\section{Material and Methods}

Six Lutjanidae species from Brazilian northeastern coast were analyzed. The species Lutjanus analis (4 male and 6 immature), L. cyanopterus (2 male), and L. jocu (1 female, 2 male and 1 immature) were collected in the estuary from Potengi River - Natal, Rio Grande do Norte (RN) 
( $5^{\circ} 46^{\prime} 43^{\prime \prime} \mathrm{S} ; 35^{\circ} 13^{\prime} 5^{\prime \prime} \mathrm{W}$ ). Samples of L. synagris (5 female, 1 male and 3 immature) and L. alexandrei ( 7 female and 2 male) came from the city of Muriú ( $5^{\circ} 33^{\prime} 41^{\prime \prime} \mathrm{S}$; $35^{\circ} 14^{\prime} 17^{\prime \prime}$ W) and Potengi River, RN while Ocyurus chrysurus (5 female) specimens were collected at shallow reefs in the city of Maracajaú, RN $\left(5^{\circ} 23^{\prime} \mathrm{S} ; 35^{\circ} 15^{\prime} \mathrm{W}\right)$.

Prior to in vitro preparation of mitotic chromosomes (Gold et al., 1990), the animals were submitted to mitotic stimulation (Lee and Elder, 1980). The nucleolar organizer regions (NORs) were detected following the technique described by Howell and Black (1980). Heterochromatin regions were identified through $\mathrm{C}$-banding according to Sumner (1972). The chromosomal preparations were photographed using a photomicroscope (Olympus BX42) equipped with a digital imaging system DP72. The chromosomes were arranged in a decreasing size order and classified according to Levan et al. (1964).

\section{Results}

The cytogenetic analyses of Lutjanus analis, $L$. alexandrei, L. cyanopterus, L. jocu, L. synagris and Ocyurus chrysurus revealed a modal value of $2 \mathrm{n}=48$ acrocentric chromosomes $(\mathrm{FN}=48)$ (Figures 1-6A).

C-banding showed reduced heterochromatic blocks, located on centromeres of the species analyzed (Figures 1-6B), except in L. analis and O. chrysurus which presented large and sharp heterochromatic regions at centromeric position in all chromosomes.

Interstitial single NORs were identified in five from the six species studied (Figure 7), equivalent to the secondary constrictions. Active ribosomal sites were located at pericentromeric region, of the $2^{\text {nd }}$ pair in $L$. alexandrei, $L$. cyanopterus and O. chrysurus, of the $5^{\text {th }}$ pair in L. analis, and of the $23^{\text {rd }}$ pair in L. synagris. Multiple NORs were found at pericentromeric region on the $2^{\text {nd }}$ pair and at telomeric position on the $5^{\text {th }}$ chromosomal pair in L. jocu (Figure 3A, detail). A numerical polymorphism in NOR sites (one to two positively stained homologous chromosomes) was observed in most of analyzed species (data not shown).

\section{Discussion}

Conservative karyotypes bearing a diploid value of $2 \mathrm{n}=48(\mathrm{FN}=48)$ are usually regarded as a typical condition of a great number of perch-like species, putatively associated with decreased levels of genetic variation among marine populations (Molina and Galetti, 2004). Therefore, the occurrence of a large number of migratory or dispersive individuals (long-phase larval planktonic stage), coupled with weak geographical barriers, may be responsible for an increased gene flow, thus leading to a genetic homogeneity in marine fish populations (Brum, 1995; Molina et al., 2002), reflected as unchanged karyotypes.

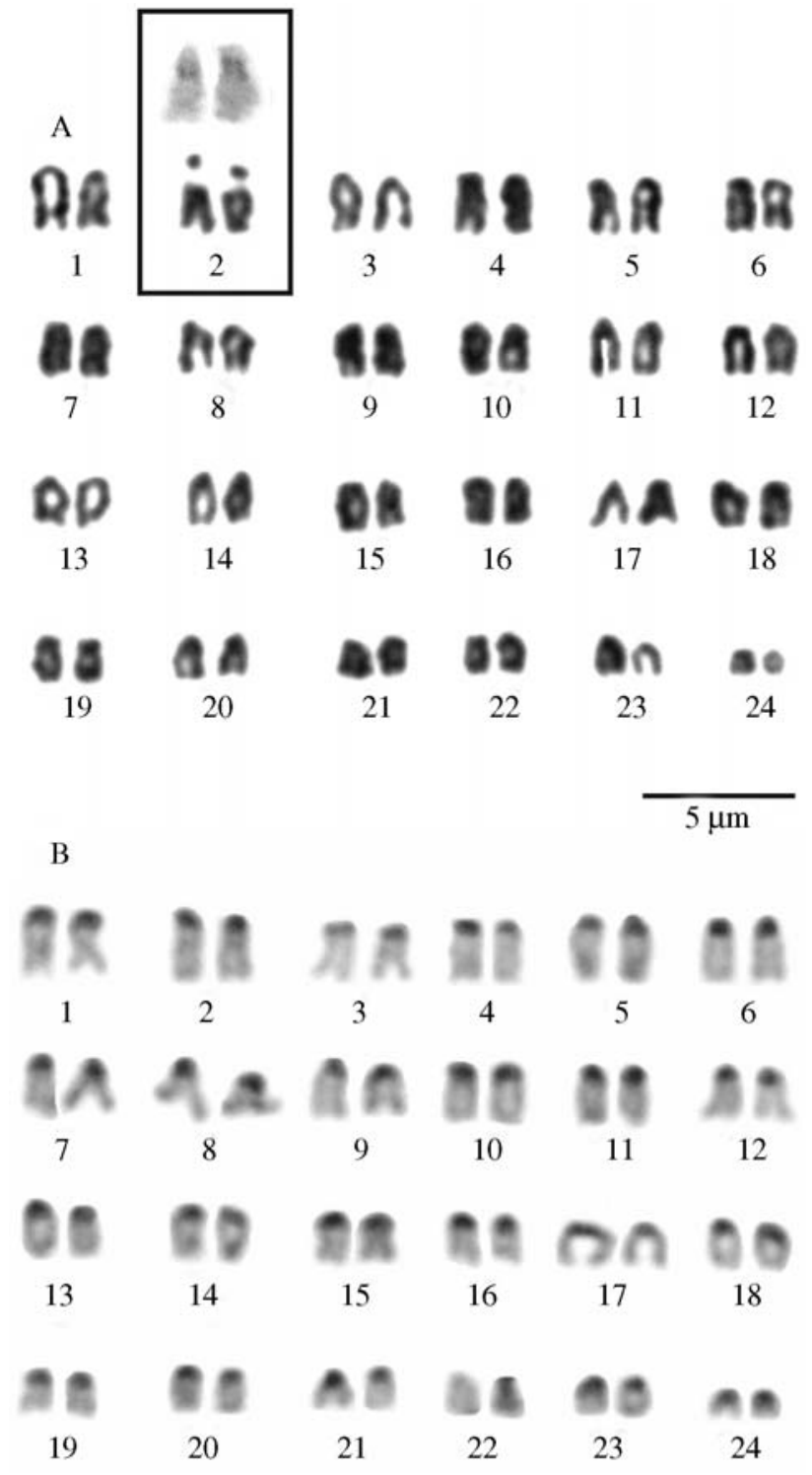

Figure 1 - Karyotype of Ocyurus chrysurus. (A) Conventional Giemsa staining. In detail, the secondary constrictions equivalent to NORs. (B) C-banding in Ocyurus chrysurus.

Previous studies have shown that there is a close relationship between karyotypic homogeneity and duration of the larval period. Species exhibiting a long-term larval phase tend to present more stable karyotypes and vice versa (Molina and Galetti, 2004). Information about the larval dispersal phase (LDP) are available for some Lutjanidae species, ranging from 25 to 40 days (Allman and Grimes, 2002; Sponaugle et al., 2003; Domeier, 2004). Such a larval pelagic period might be considered as relatively long, likely favoring karyotypic homogeneity observed in the analyzed species, which share the conserved karyotype pattern of Perciformes, with 48 acrocentric chromosomes (Molina et al., 2002).

Another fact that should be taken into account for the maintenance or diversification of Perciformes karyotypes 


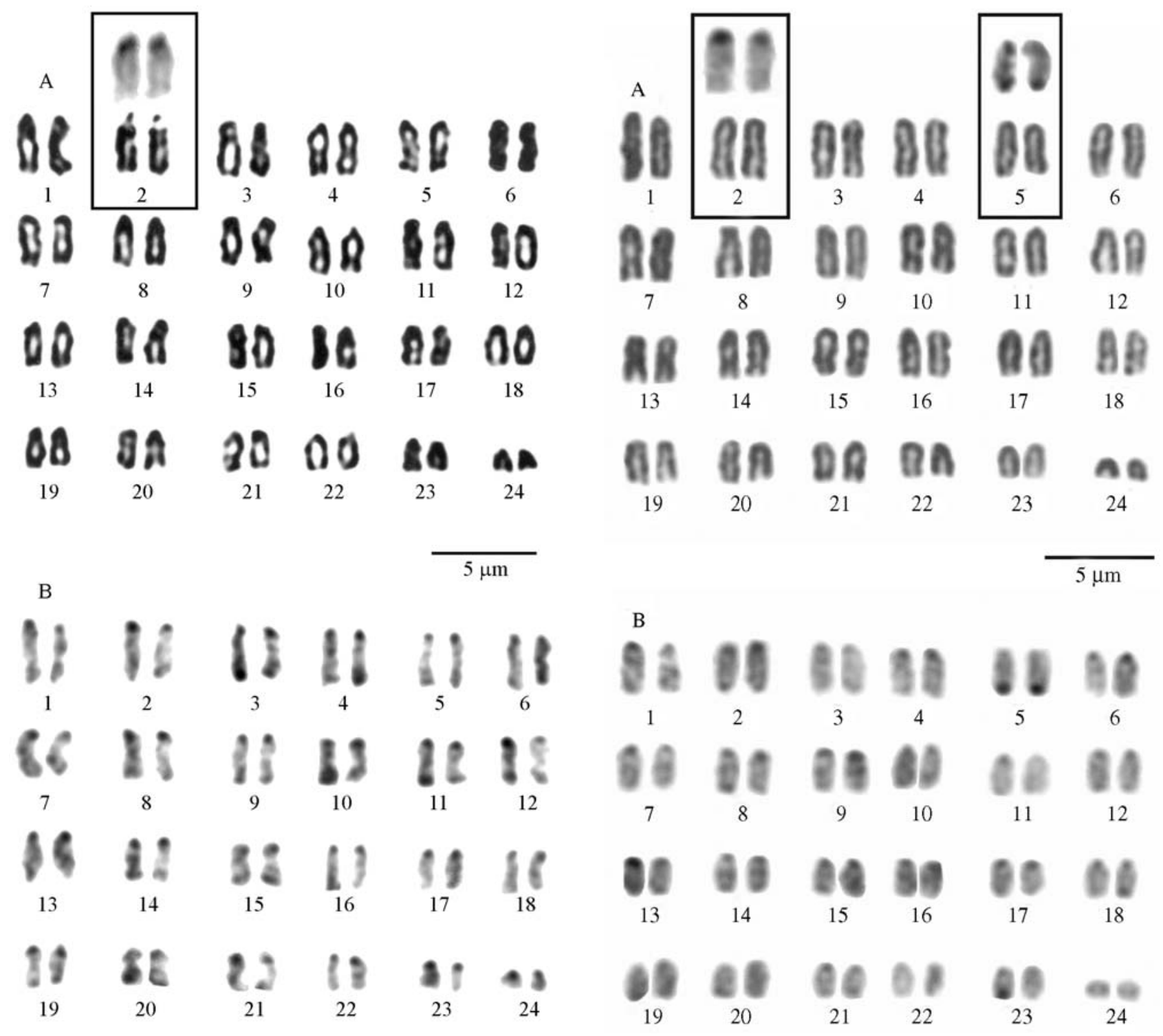

Figure 2 - Karyotype of Lutjanus alexandrei. (A) Conventional Giemsa staining. In detail, the secondary constrictions equivalent to NORs. (B) C-banding in L. apodus.

is the role of heterochromatin in chromosomal dynamics (Molina, 2006). Such segments can be amplified or accumulated by unequal crossovers, transpositions and/or duplications, as suggested for the marine pigmy angelfish, Centropyge aurantonotus (Affonso and Galetti, 2005). Evidence of karyotypic differentiation related to variation in number, size and location of heterochromatic segments has been extensively provided in fish species (Moreira-Filho et al., 1984; Galetti et al., 1991; Bertollo, 1996; Margarido and Galetti, 1996 among others). Cases of heterochromatin polymorphism might range from subtle to hypervariable in fish. They can be related to the size of the heterochromatic blocks (Martinez et al., 1991; Jankun et al., 1998) or to associations between heterochromatin and NORs (Hartley, 1988; Amores et al., 1993). Some groups, particularly the

Figure 3 - Karyotype of Lutjanus jocu. (A) Conventional Giemsa staining. In detail, the NOR-bearing pairs. (B) C-banding in L. jocu .

Characiformes, present a remarkable karyotype variability influenced by heterochromatinization processes, as extensively seen in the species complex Astyanax scabripinnis (Souza et al., 1996; Mantovani et al., 2000; Mantovani et al., 2004).

The reduced heterochromatin content over centromeric regions in chromosomes of the four lutjanids herein studied (Lutjanus alexandrei, L. cyanopterus, L. synagris and $L . j o c u$ ) reveals a similar feature to that observed in several species of the families Haemulidae, Serranidae and Pomacentridae (Molina, 2006). Such a condition seems to be frequent among lutjanids and apparently has a considerable bearing on the stabilization of karyotypic differentiation processes, mainly numerical ones (Molina and Galetti, 2004). However, the chromosomal conservativeness in 


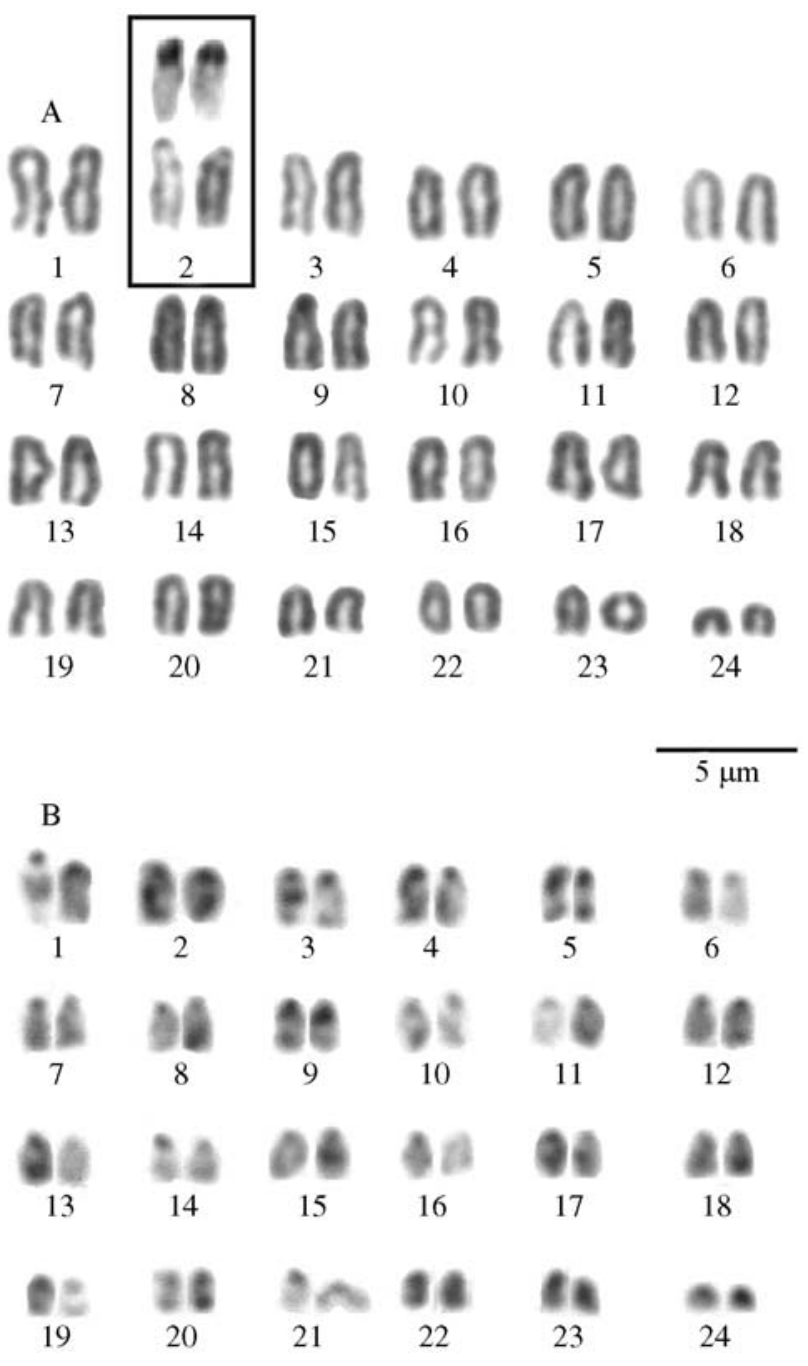

Figure 4 - Karyotype of Lutjanus cyanopterus. (A) Conventional Giemsa staining. In detail, the secondary constrictions equivalent to NORs. (B) C-banding in Lutjanus cyanopterus.

snappers does not exclude the presence of some degree of structural diversification, presently undetected.

Conserved karyotypes, concerning both diploid number and chromosomal types, have been extensively identified within the family Haemulidae, phylogenetically related to Lutjanidae. Several genera, such as Haemulon, Conodon, Pomadasys and Anisotremus have presented a typical perch-like karyotype $(2 \mathrm{n}=48 \mathrm{a})$. These results reveal a basal condition shared by both families. Possibly, the lack of major rearrangements in these groups was replaced by internal changes in linkage clusters, apparently as effective as the former in establishing post-zygotic barriers during speciation processes (Molina, 2006).

An additional feature shared by Lutjanidae and Haemulidae is the presence of single NORs located at an interstitial position on acrocentric chromosomes. Such a condition was observed in $L$. alexandrei, $L$. analis, $L$. cyanopterus, L. synagris and O. chrysurus and it is re-

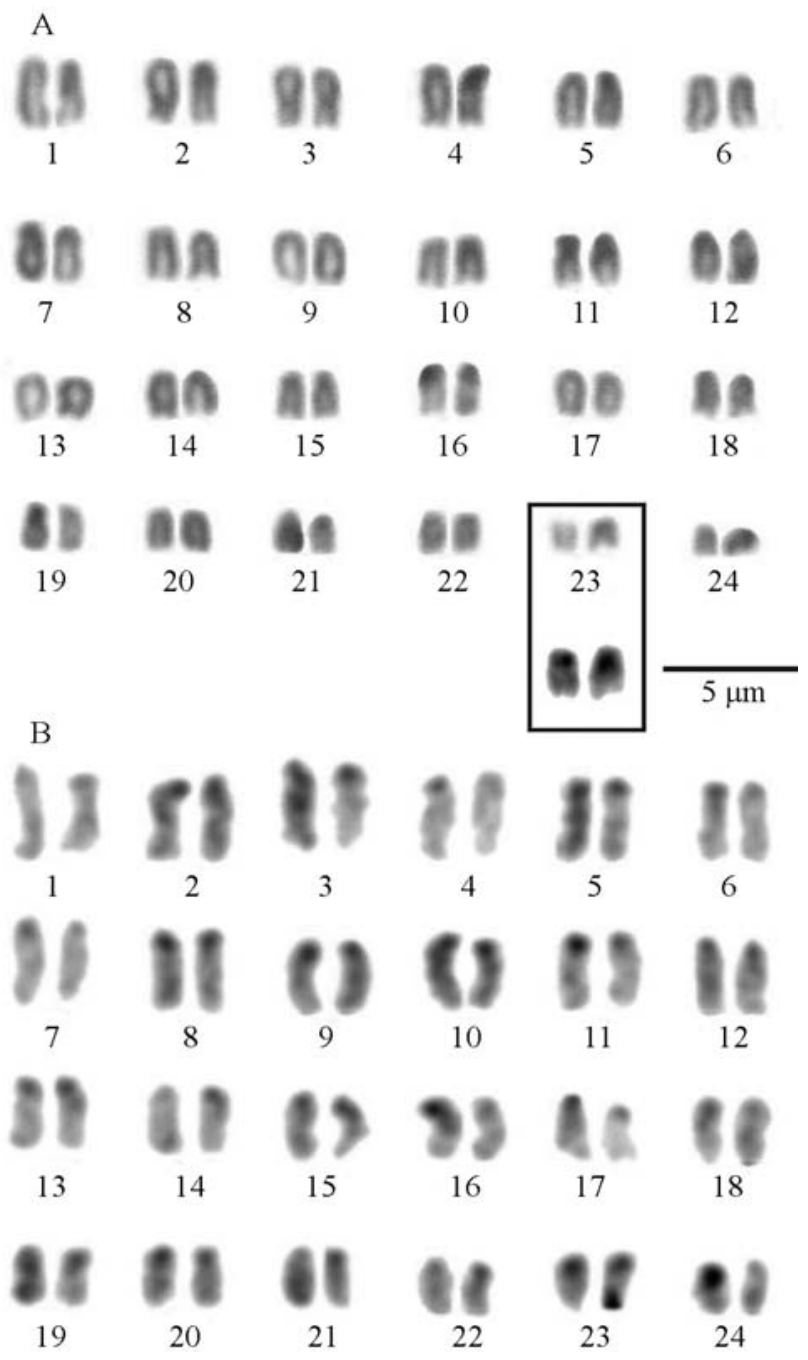

Figure 5 - Karyotype of Lutjanus synagris. (A) Conventional Giemsa staining. In detail, the secondary constrictions equivalent to NORs. (B) C-banding in Lutjanus synagris.

garded as a basal feature in several Perciformes families, such as Serranidae (Aguilar and Galetti, 1997), Pomacanthidae (Affonso et al., 2001), among others, thus corroborating the presupposition that this should be a basic pattern for the order (Galetti et al., 2000; Affonso and Galetti, 2005).

The karyotypes of the species $O$. chrysurus and $L$. analis, which bear elevated heterochromatin contents, suggest that heterochromatinization processes have occurred independently and represent a derived character for this family. However, despite the macrostructural similarity among karyotypes, the lutjanids presented a relative diversification in the location of ribosomal sites. Thus, interstitial Ag-NORs on large chromosomal pairs have been detected in L. alexandrei, L. cyanopterus and O. chrysurus $\left(2^{\text {nd }}\right.$ pair $)$, on middle-sized chromosomes in $L$. analis $\left(5^{\text {th }}\right.$ pair), and on small ones in L. synagris $\left(23^{\text {rd }}\right.$ pair $)$, or even as multiple sites in $L$. jocu $\left(2^{\text {nd }}\right.$ and $5^{\text {th }}$ pairs $)$. 


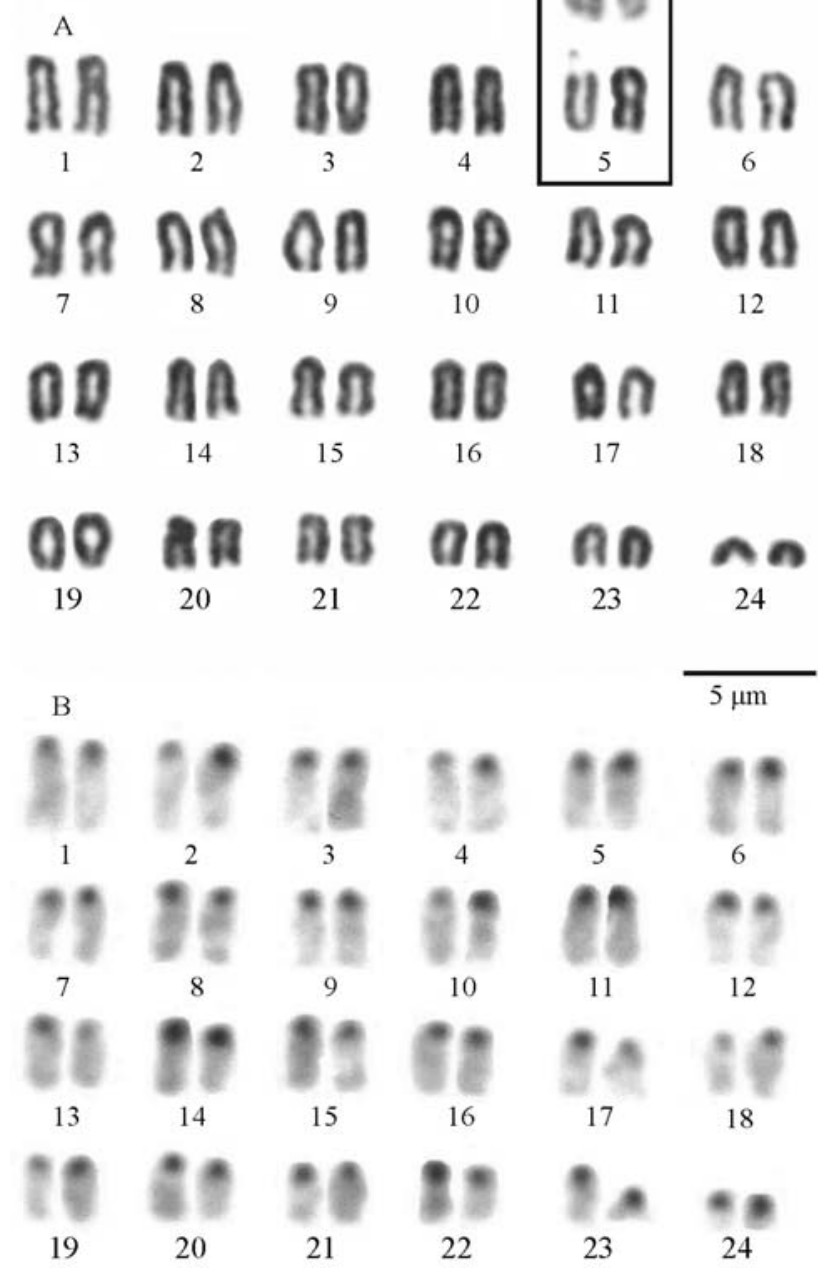

Figure 6 - Karyotype of Lutjanus analis. (A) Conventional Giemsa staining. In detail, the secondary constrictions equivalent to NORs. (B) C-banding in Lutjanus analis.

Multiple NORs have rarely been reported in Perciformes (Galetti et al., 2000), although they are common in Characiformes and Siluriformes (Mantovani et al., 2000; Paintner-Marques et al., 2002). Mostly, such variation results from chromosomal rearrangements, but transposition events have also been indicated as one major factor for the numerical variability of NORs in fishes (Galetti et al., 1995; Almeida-Toledo et al., 1996; Castro et al., 1996; Vitturi et al., 1996).

The nucleolar organizer regions are effective cytotaxonomic markers in Lutjanidae and allowed us to distinguish most of the analyzed species, except for $O$. chrysurus, L. alexandrei and L. cyanopterus, in which the ribosomal sites were similarly located on the same chromosomal pair $\left(2^{\text {nd }}\right.$ pair). Cytogenetic studies in other groups with conserved karyotypes have also demonstrated the same discriminatory ability of NORs, such as in Anostomidae (Galetti et al., 1984) and in some Cichlidae (Brinn et al.,

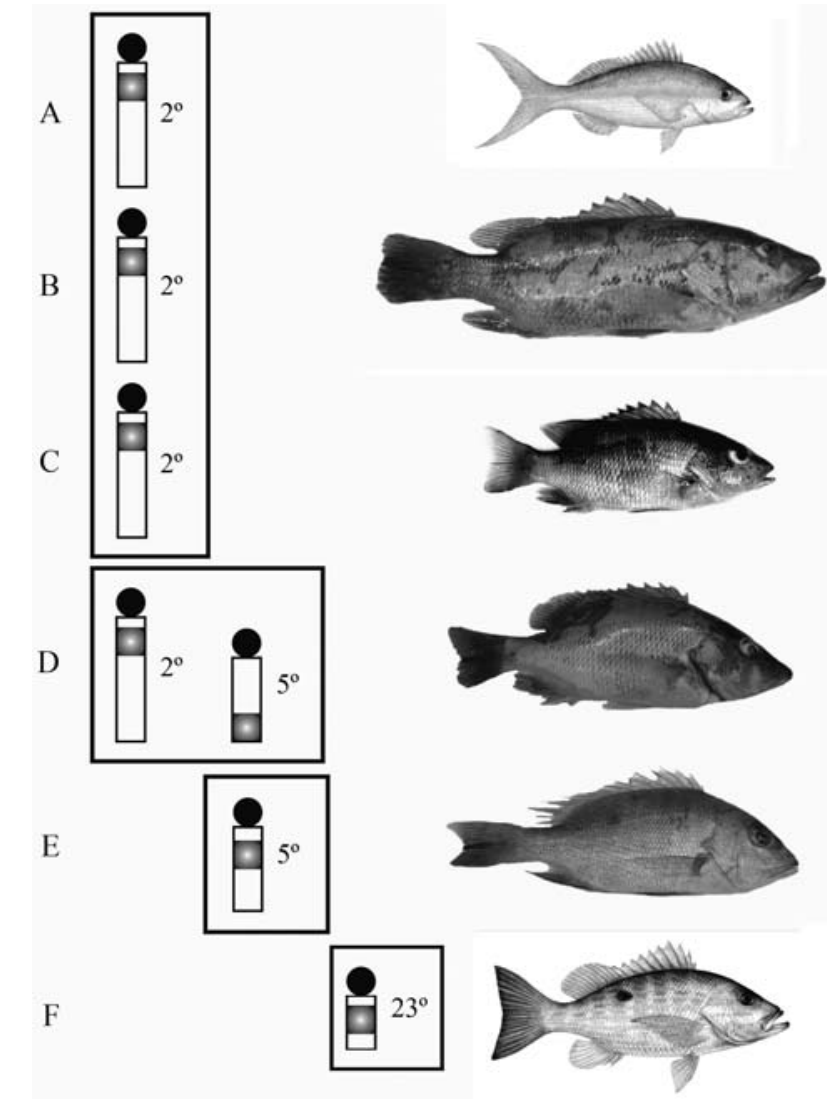

Figure 7 - Representative picture of the number and location of ribosomal sites on NOR-bearing chromosomes of $O$. chrysurus (A), L. cyanopterus (B), L. alexandrei (C), L. jocu (D), L. analis (E), and L. synagris (F).

2004). However, the efficiency of ribosomal sites as a cytotaxonomic marker is not applicable to all situations, since these regions might remain unchanged on homeologous chromosomes of several species (Feldberg and Bertollo, 1985; Molina and Galetti, 2004).

Some phylogenetic inferences have been drawn from morphometric features (Rivas, 1966; Vergara 1980; Chow and Walsh, 1992), allozymes (Chow and Walsh, 1992) and mtDNA sequences (Sarver et al., 1996) for the family Lutjanidae. From these inferences a consensus of closer phylogenetic relationships among $L$. apodus, L. griseus, $L$. synagris and $L$. analis emerged.

The presence of ribosomal sites on a large acrocentric pair has been considered a plesiomorphic characteristic amongst Perciformes, being typical of Serranidae (Molina et al., 2002), Pomacanthidae and Chaetodontidae (Affonso et al., 2001), and Cichlidae (Feldberg and Bertollo, 1985). Analyzing the karyotypes of Lutjanidae species considered by phylogenetic studies as some of the most derived ones (such as L. jocu, L. analis and L. synagris) we observed that NORs were significantly more variable in these species (pairs 5/2, 5 and 23, respectively).

Phylogenetic data in Lutjanidae, based on mitochondrial sequences, indicated that Ocyurus is the most closely 
related genus to Lutjanus and that L. cyanopterus would represent the most basal form in this clade (Sarver et al., 1996). These data are corroborated by the present cytogenetic analyses. These species present conserved karyotypes with respect to their macrostructure and bear ribosomal sites at an interstitial position on the second chromosomal pair, a plesiomorphic condition for the family that is also found in the species L. alexandrei.

Up to now, there are no conclusive theories to explain the chromosomal conservativeness observed in several Perciformes families, such as the Lutjanidae, although some hypotheses have been proposed, mainly those involving karyotypic orthoselection (Molina et al., 2002; Molina and Galetti, 2002; Molina, 2006). Studies utilizing methods of higher banding frequency and localization of specific sequences in the karyotype might help to elucidate the actual degree of chromosomal conservativeness for this group and for other Perciformes representatives, further contributing to our understanding of their evolutionary patterns.

\section{Acknowledgments}

The authors would like to thank José Garcia Júnior for help us with taxonomic identification. This research was supported by Conselho Nacional de Desenvolvimento Científico e Tecnológico (CNPq), Brazil.

\section{References}

Affonso PRAM and Galetti PM (2005) Chromosomal diversification of reef fishes from genus Centropyge (Perciformes, Pomacanthidae). Genetica 123:227-233.

Affonso PRAM, Guedes W, Pauls E and Galetti PM (2001) Cytogenetic analysis of coral reefs fishes from Brazil (Families Pomacanthidae and Chaetodontidae). Cytologia 66:379-384.

Aguilar CT and Galetti PM (1997) Chromosomal studies in South Atlantic serranids (Pisces, Perciformes). Cytobios 89:105114.

Allman RJ and Grimes CB (2002) Temporal and spatial dynamics of spawning, settlement, and growth of gray snapper (Lutjanus griseus) from the West Florida shelf as determined from otolith microstructures. Fish Bull 100:391-403.

Almeida-Toledo LF, Bigoni AP, Bernardino G, Foresti F and Toledo-Filho SA (1996) Karyotype and NOR conservatism with heterochromatin reorganization in Neotropical bryconids. Caryologia 49:35-43.

Amores A, Martinez G, Reina J and Alvarez MC (1993) Karyotype, C-banding, and Ag-silver NOR analysis of Diplodus bellottii (Sparidae, Perciformes): Intra-individual polymorphism involving heterochromatic regions. Genome 36:672675.

Bertollo LAC (1996) The nuclear organizer regions of Erythrinidae fish. An uncommon situation in the genus Hoplias. Cytologia 61:75-81.

Brinn MNA, Porto JIR and Feldberg E (2004) Karyological evidence for interespecific hybridization between Cichla monoculus and C. temensis (Perciformes, Cichlidae) in the Amazon. Hereditas 141:252-257.
Brum MJI (1995) Correlações entre a filogenia e a citogenética dos peixes teleósteos. Rev Bras Genet, Série Monografias 2:5-42.

Castro J, Viñas A, Sánchez L and Martínez P (1996) Characterization of an atypical NOR site polymorphism in brown trout (Salmo trutta) with Ag- and CMA3-staining, and fluorescent in situ hybridization. Cytogenet Cell Genet 75:234-239.

Cervigón F (1993) Los Peces Marinos de Venezuela. 2ra edición, v II. Fundación Científica Los Roques, Caracas, 498 pp.

Chow S and PJ Walsh (1992) Biochemical and morphometric analyses for phylogenetic relationships between seven snapper species (Subfamily, Lutjaninae) of the western Atlantic. Bull Mar Sci 50:508-519.

Coleman FC, Koenig CC, Huntsman GA, Musick JA, Eklund AM, McGovern JC, Chapman RW, Sedberry GR and Grimes CB (2000) Long-lived reef fishes: The grouper snapper complex. Fisheries 25:14-21.

Choudhury RC, Prasad R and Das CC (1979) Chromosomes of six species of marine fishes. Caryologia 32:15-21.

Domeier ML (2004) A potential larval recruitment pathway originating from a Florida marine protected area. Fish Oceanogr 13:287-294.

España HP (2003) Ecological importance of snappers in the stability of modeled costal ecosystems. Ecol Model 168:13-24.

Feldberg E and Bertollo LAC (1985) Nucleolar organizing regions in some species of neotropical cichlid fish (Pisces, Perciformes). Caryologia 34:319-324.

Galetti Jr PM, Foresti F, Bertollo LAC and Moreira-Filho O (1984) Characterization of eight species of Anostomidae (Cypriniformes) fish on the basis of the nucleolar organizing region. Caryologia 4:401-406.

Galetti PM, Cesar ACG and Venere PC (1991) Heterochromatin and NORs variability in Leporinus fish (Anostomidae, Characiformes). Caryologia 44:287-292.

Galetti Jr PM, Mestriner CA, Monaco PJ and Rasch EM (1995) Post-zygotic modifications and intra- and inter-individual nucleolar organizing region variations in fish: Report of a case involving Leporinus friderici. Chrom Res 3:285-290.

Galetti Jr PM, Aguilar CT and Molina WF (2000) An overview on marine fish cytogenetics. Hydrobiologia 420:55-62.

Gold JR, Li C, Shipley NS and Powers PK (1990) Improved methods for working with fish chromosomes with a review of metaphase chromosome banding. J Fish Biol 37:563-575.

Hartley SE (1988) Cytogenetic studies of Atlantic salmon, Salmo salar L., in Scotland. J Fish Biol 33:735-740.

Howell WM and Black DA (1980) Controlled silver staining of nucleolus organizer region with protective colloidal developer: A 1-step method. Experientia 36:1014-1015.

Jankun M, Ocalewicz K and Woznicki P (1998) Replication, Cand fluorescent chromosome banding patterns in European whitefish, Coregonus lavaretus L. Hereditas 128:195-199.

Lee MR and Elder FFB (1980) Yeast stimulation of bone marrow mitosis for cytogenetic investigations. Cytogenetic Cell Genet 26:36-40.

Levan A, Fredga K and Sandberg AA (1964) Nomenclature for centromeric position on chromosomes. Hereditas 52:201220 .

Mantovani M, Abel LDS, Mestriner CA and Moreira-Filho O (2000) Accentuated polymorphism of heterochromatin and nucleolar organizer regions in Astyanax scabripinnis (Pis- 
ces, Characidae): Tools for understanding karyotypic evolution. Genetica 109:161-168.

Mantovani M, Abel LDS, Mestriner CA and Moreira-Filho O (2004) Evidence of the differentiated structural arrangement of constitutive heterochromatin between two populations of Astyanax scabripinnis (Pisces, Characidae). Genet Mol Biol 27:536-542.

Margarido VP and Galetti PM (1996) Chromosome studies in fish of the genus Brycon (Characiformes, Characidae, Bryconinae). Cytobios 85:219-228.

Martinez P, Vinas A, Bouza C, Arias J, Amaro R and Sanchez L (1991) Cytogenetical characterization of hatchery stocks and natural populations of sea and brown trout from Northwestern Spain. Heredity 66:9-18.

Molina WF (2006) Chromosome changes and stasis in marine fish groups. In: Pisano E, Ozouf-Costaz C, Foresti F and Kapoor BG (eds) Fish Cytogenetics. Science Publishers, Enfield, pp 69-110.

Molina WF and Galetti Jr PM (2002) Robertsonian rearrangements in the reef fish Chromis (Perciformes, Pomacentridae) involving chromosomes bearing 5S rRNA genes. Genet Mol Biol 25:373-377.

Molina WF and Galetti PM (2004) Multiple pericentric inversions and chromosome divergence in the reef fishes Stegastes (Perciformes, Pomacentridae). Genet Mol Biol 27:543-548.

Molina WF, Maia-Lima F and Affonso PRAM (2002) Divergence between karyotypical pattern and speciation events in Serranidae fish (Perciformes). Caryologia 55:299-305.

Moreira-Filho O, Bertollo LAC and Galetti Jr PM (1984) Structure and variability of nucleolar organizer regions in Parodontidae fish. Can J Genet Cytol 26:564-568.

Moura RL and Lindeman KC (2007) A new species of snapper (Perciformes, Lutjanidae) from Brazil, with comments on the distribution of Lutjanus griseus and L. apodus. Zootaxa 1422:31-43.

Nelson JS (2006) Fishes of the World. 4th edition. John Willey and Sons Inc., New York, 601 pp.

Paintner-Marques TR, Giuliano-Caetano L and Dias AL (2002) Multiple NORs in Bryconamericus aff. exodon
(Osteichthyes, Characidae, Tetragonopterinae). Hereditas 137:107-112.

Polovina JJ and Ralston S (1987) Tropical Snappers and Groupers: Biology and Fisheries Management. Westview Press, Boulder, $659 \mathrm{pp}$.

Raghunath P and Prasad R (1980) Chromosomes of six marine percoids from the Indian Sea. Ind Biol 11:9-12.

Resende SM, Ferreira BP and Thierry F (2003) A pesca de lutjanídeos no nordeste do Brasil: Histórico das pescarias, características das espécies e relevância para o manejo. Bol Téc CEPENE, v 11.

Rishi KK (1973) A preliminary report on the karyotypes of eighteen marine fishes. Res Bull (NS) Panjab Univ 24:154-162.

Rivas LR (1966) Review of the Lutjanus campechanus complex of red snappers. Q J Fla Acad Sci 29:117-136.

Sarver SK, Freshwater DW and Walsh PJ (1996) Phylogenetic relationships of Western Atlantic snapper (Family Lutjanidae) based on mitochondrial DNA sequences. Copeia 3:715-721.

Souza IL, Moreira-Filho O and Galetti Jr PM (1996) Heterochromatin differentiation in the characid fish Astyanax scabripinnis. Braz J Genet 19:405-410.

Sponaugle S, Fortuna J, Grorud K and Lee T (2003) Dynamics of larval fish assemblages over a shallow coral reef in the Florida Keys. Mar Biol 143:175-189.

Sumner AT (1972) A simple technique for demonstrating centromeric heterochromatin. Expl Cell Res 75:304-306.

Ueno K and Takai A (2008) Multiple sex chromosome system of $\mathrm{X}_{1} \mathrm{X}_{1} \mathrm{X}_{2} \mathrm{X}_{2} / \mathrm{X}_{1} \mathrm{X}_{2} \mathrm{Y}$ type in lutjanid fish, Lutjanus quinquelineatus (Perciformes). Genetica 132:35-41.

Vergara RR (1980) Consideraciones filogeneticas sobre las espécies cubanas gênero Lutjanus (Lutjanidae, Perciformes, Teleostei). Informe Científico-Téchnico 113:1-39.

Vitturi R, Libertini A, Mazzola A, Colomba MS and Sara G (1996) Characterization of mitotic chromosomes of four species of the genus Diplodus: Karyotypes and chromosomal nucleolar organizer region phenotypes. J Fish Biol 49:1128-1137.

Associate Editor: Fausto Foresti

License information: This is an open-access article distributed under the terms of the Creative Commons Attribution License, which permits unrestricted use, distribution, and reproduction in any medium, provided the original work is properly cited. 